\title{
高速道路経路選択行動における評価要因の因果構造特性：地域間比較分析”
}

\section{Some Characteristics of Causal Structures underlying Highway Route Choice Behavior : A Comparative Analysis}

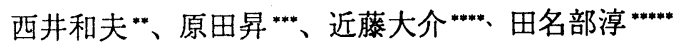

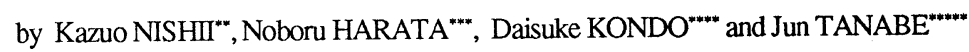

\section{1 はじめに}

わが国の高速道路ネットワークは、その建設整備 によってますます広域化・複雑化の傾向にある。この ようなネットワーク上では、経路選択要因としての 「料金」「所要時間」に関して比較的類似した経路が複 数存在するため、その場合に利用者は、「安全性」や 「ルートのわかり易さ」といった定性的評価要因をも 考慮しながら経路選択を行うものと考えられる。経 路選択行動における定性的な評侀要因に関する分析 意義はこのように大きいが、これらの要因はその計 量化の困難さ故に、項目の抽出や抽象的な表現にと どまる場合が少なくなかった。しかし、これからの高 速道路経路選択行動の的確な把握のためには、これ らの項目についても明示的に取扱うとともに、経路 選択行動への影響をトータルなものとして扱うこと のできる評価分析フレームの開発が必要といえる。

そこで、本研究では、共分散構造分析 (LISREL モ デル)の適用を通じて、経路選択行動における評価要 因の因果構造モデルの構築を試みる。このモデルは、 「潜在変数 (実際には観測不可能な変数)」を導入する ことによって内容の似通ったいくつかの「観测变数 (手元にデータとしてある観測可能な変数)」を潜在 因子で縮約するとともに、これら潜在変数抏よび観 測変数間の因果関係を分析できる特徵をもつ。言い 換えれば、道路の「安全性」や「わかり易さ」といっ た計量化が困難な定性的要因に対して潜在变数を介 することで、それらと観測可能な变数との因果構造 を表現し、その諸特性を把握できる。

以下では、図-1に示すように、まず第一に平成6年 度実施の高速道路利用者アンケート調査データを用

\footnotetext{
*Keywords：経路選択、交通行動分析

“正会貝 工博 山梨大学工学部:士木環境工学科 （山梨県甲府市武田 4-3-11、Tel\&Fax.0552-20-8533）

…正会貝 工博 東京大学工学部都市工学科

…学生員山梨大学大学院士本環境工学専攻

……正会員都市交通計画研究所
}

いて、経路選択評価要因を軸にした基礎集計分析か ら経路選択行動の実態を把握するとともに、「料金」 「所要時間」に関する以外の定性的要因を抽出する。 次いで、「経路選択評価要因」「選択結果」「個人属性」 「ルート側の種々の条件」等を変数として用いた LISREL モデルを構築し、そのモデルを現在 ODペア に2通りの高速道路ルートを持つ3つの地域に適用さ せる。そして、推計結果と基礎集計結果との対比およ び地域間比較を通じて、提案LISRELモデルがどのよ うに的確に経路選択行動の評価要因構造を表現でき ているのか、その有効性を検証する。

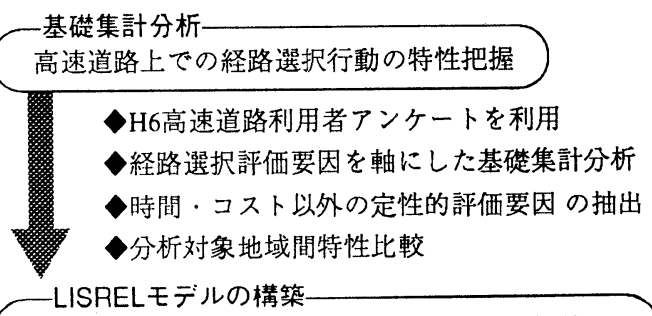
定性的評侕要因の構造を表す基本モデルの構築
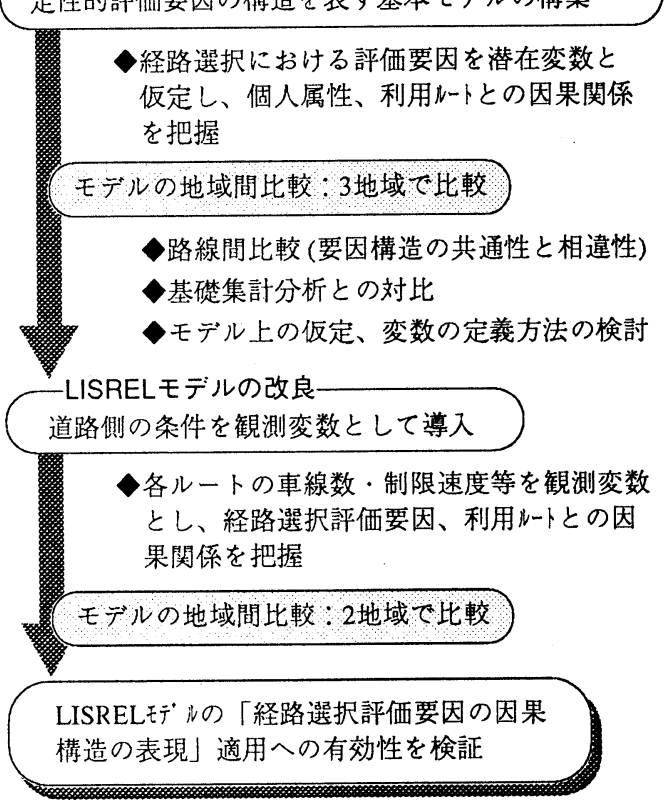

図-1 本研究のフロー 


\section{2 分析データの概要と基礎集計分析}

\section{(1) 分析データ}

本研究では、高速道路利用経路がループ状になっ ている東京〜名古屋、名古屋〜大阪、広島～山口間の $\mathrm{SA} \cdot \mathrm{PA}$ に扔いて、平成 6 年に実施された高速道路利 用者アンケート調査データを分析対象とした。1)表一 1 に対象地域に打ける各ルートの母数とサンプル数、 図 -2に分析対象とした 3 地域の概要を掲載する。

\section{（2）経路選択行動の因果構造の仮定}

本研究では、高速道路上での経路選択行動の因果 構造を図-3のように仮定した。この図では、選択結 果である「利用経路」は所要時間が短いから・走りや すいから等の「経路選択評価要因」により決定され、 それら評価要因は「個人属性・トリップ特性」と「道 路特性」によって規定されることを示している。

ここで、高速道路利用者アンケートでは表-2の 12 項目の中から実際に利用した経路についてその選択 理由を回答 (複数回答可)させているが、本砳究では 例えば、所要時間が短い・距離が短い・時間が正確と いう理由は「時間選好性」であると仮定した。このよ

表-1 各ルートの母数とサンプル数

\begin{tabular}{|l|c|c|c|c|c|}
\hline \multirow{2}{*}{ 対象地域 } & \multirow{2}{*}{ 路線 } & \multicolumn{2}{|c|}{ 母数* } & \multicolumn{2}{l|}{ 抽出サンブ } \\
& & 分担率 & 数 (人) & 分担率 \\
\hline 東京 & 東名高速 & 30504 & $76 \%$ & 407 & $49 \%$ \\
～名古屋 & 中央道 & 9500 & $24 \%$ & 429 & $51 \%$ \\
\hline 名古屋 & 名神高速 & 23122 & $75 \%$ & 247 & $39 \%$ \\
～大阪 & 東名阪 & 7744 & $25 \%$ & 379 & $61 \%$ \\
\hline 広島 & 中国道 & 11472 & $63 \%$ & 371 & $30 \%$ \\
～山口 & 山陽道 & 6660 & $37 \%$ & 861 & $70 \%$ \\
\hline
\end{tabular}

注*) 母数は図-2のICペア間における利用台数で $\mathrm{JH}$ 業務実績（平成6年11月の日平均）にもとつ゚く

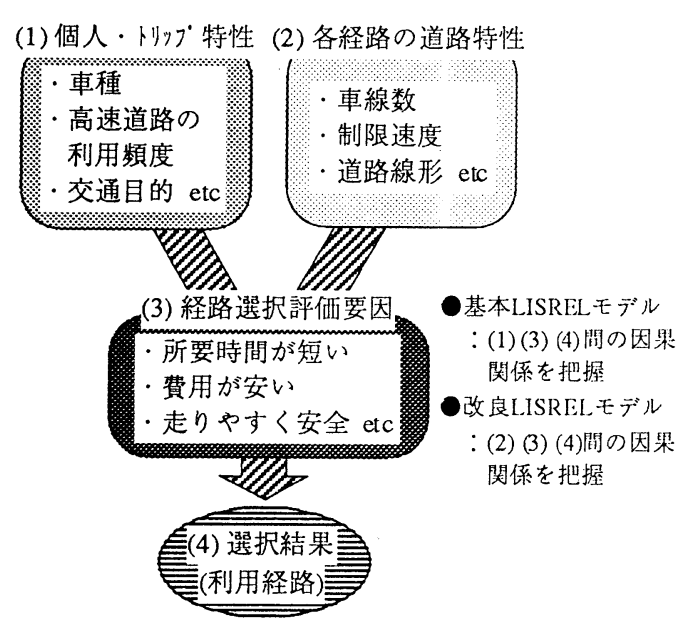

図-3本研究で仮定した経路選択行動の因果棈造

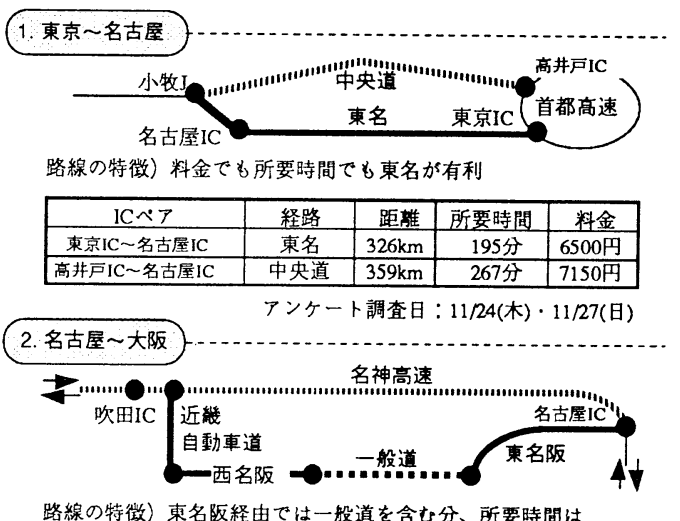

路線の特徽)東名阪経由では一段道を含む分、所要時間は かかるが料金が安い。

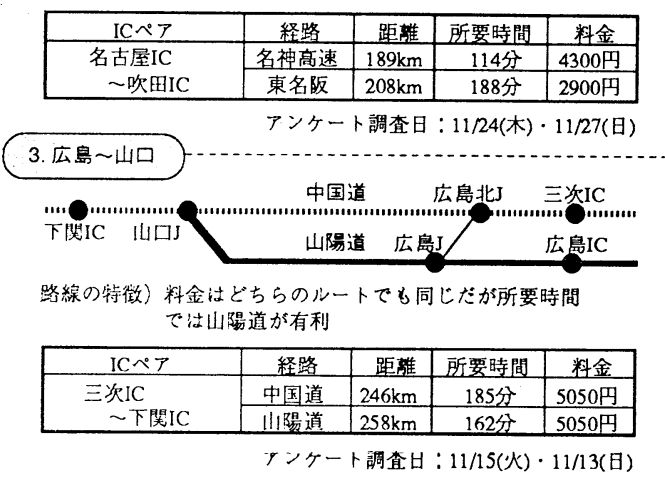

図-2 分析対象地域の概要

うに 12 の選択理由を $6 つ の$ 要因に集約し、それらを 経路選択評洒要因として以降の分析を進めた。

\section{（3）経路選択評価要因に関する基礎集計分析}

図 -4 は、経路選択評価要因の構成を示す。これよ り、高速道路利用者は経路選択の際、所要時間や料 金に関する要因だけでなく、「安全性」「ルートの自 由選択性」「ルートのわかり易さ」といった定性的な 要因も考慮しているといえる。また、各ルートで評価

表-2 経路㩔択評価要因の分類と複数回答可での回答頻度

\begin{tabular}{|c|c|c|c|c|}
\hline 評価要因 & アンケートでの回答内容 & 東京名古屋 & 名古䚄吸 & 広島山口 \\
\hline \multirow{3}{*}{ 時閉避好性 } & 1）所要時間が短い & $21 \%$ & $23 \%$ & $19 \%$ \\
\hline & 2) 距陮が短い & $8 \%$ & $16 \%$ & $20 \%$ \\
\hline & 3）時問が正確 & $8 \%$ & $3 \%$ & $3 \%$ \\
\hline 経济性 & 4）䩀用が安い & $2 \%$ & $21 \%$ & $4 \%$ \\
\hline 安全性 & 5）走りやすく安全 & $21 \%$ & $9 \%$ & $24 \%$ \\
\hline \multirow{2}{*}{$\begin{array}{l}\text { ルートの } \\
\text { 自由还択性 }\end{array}$} & 6)このルートを走るのが好き & $7 \%$ & $2 \%$ & $4 \%$ \\
\hline & 7）往復でルートを変えたかった & $3 \%$ & $1 \%$ & $2 \%$ \\
\hline \multirow{3}{*}{$\begin{array}{l}\text { ルートの } \\
\text { かかり易さ }\end{array}$} & 8）以前に通ったことがある & $4 \%$ & $4 \%$ & $6 \%$ \\
\hline & 9）ルートがわかり易い & $6 \%$ & $7 \%$ & $4 \%$ \\
\hline & 10）他ルートを知らない & $3 \%$ & $2 \%$ & $1 \%$ \\
\hline \multirow{2}{*}{ その他 } & 11）経路が指定されていた & $4 \%$ & $5 \%$ & $2 \%$ \\
\hline & 12）その他 & $13 \%$ & $7 \%$ & $12 \%$ \\
\hline
\end{tabular}

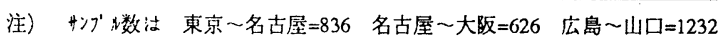




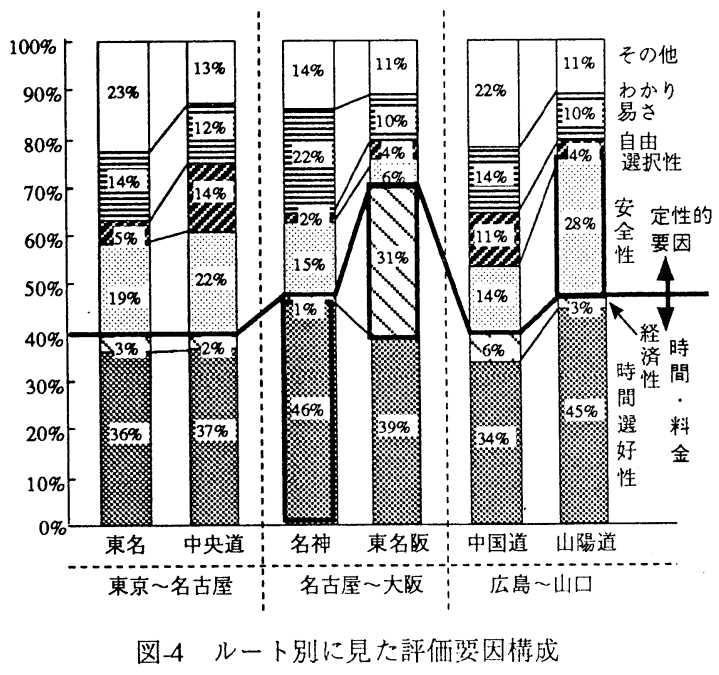

要因の構成上の差異も見られる。例えば、東名と中央 道とでは所要時間・料金の両者ともに差があるにも かかわらず、「時問選好性」や「経済性」の割合に大 きな差は見られない。(たたし、ここでの「洔間選好 性」に対する回答はIC間だけでなくアクセス・イグ レス側での所要時間を含めた回答であると考えるべ きことに注意する必要がある。）また雨ルートの比較 では、中央道で「ルートの自由選択性」の割合が高い ことが特徵的である。

一方、名古屋〜大阪間においては、名神高速で「洔 間選好性」の割合が高く、東名阪で「経済性」が高 い。この区間では図-2に示したように利用ルートに より所要時間と料金に大きな差晶があるため、評洒 要因の構成上も明確な違いが現れたものと推察され る。

さらに、広島〜山口では、山陽道で「時間選好性」 と「安全性」の割合が中国道より高い。(ここで、山 陽道の「時間選好性」が高いのは、同ルートの所羿時 間が中国道より短いことによるものと考えられる。）

\section{3 経路選択の因果構造モデルの構築}

\section{（1）基本 LISREL モデル}

ここでは、高速道路利用者の経路選択評洒要因の 構造を明らかにするため、LISRELモデルの具体的な 適用をはかる。な挍、交通研究に抢ける共分散權造分 析の適用例は最近数多く見られ、意識評俩構造の把 握や主観值デー夕に基づく意思決定分析に広く供さ れている。2)-6)

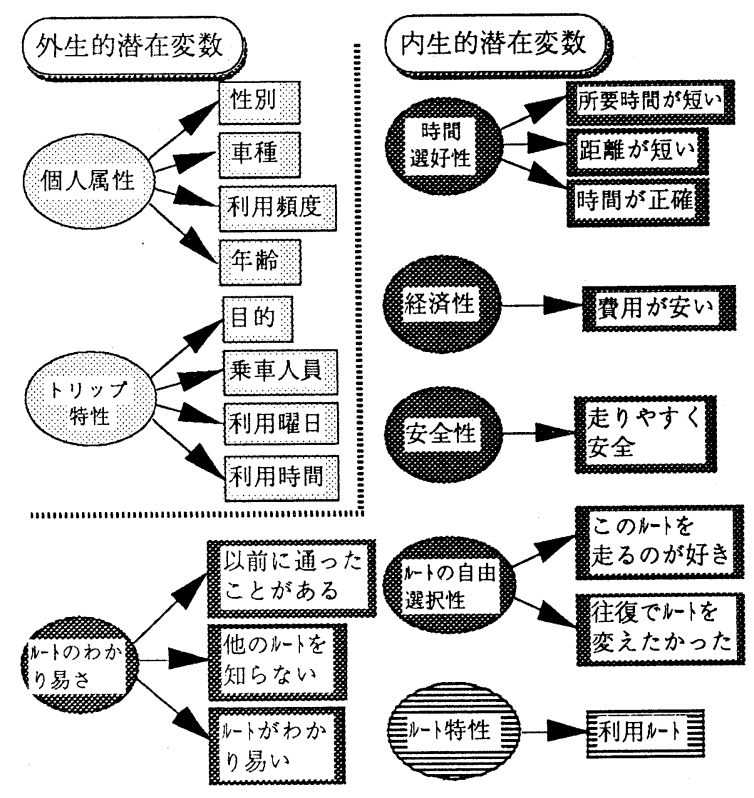

図-5 潜在変数の定義

表-3 変数の具体的設問形式

\begin{tabular}{|c|c|c|c|c|}
\hline \multicolumn{2}{|l|}{ 個人属性 } & \multicolumn{2}{|c|}{ トリッブ特性 } & 严ルート属性三 \\
\hline \multirow{2}{*}{$\begin{array}{l}\text { 利用頻度（回） } \\
\text { (年問利用回数) }\end{array}$} & 性別 & 利用目的 & 乗車人貣 & \multirow{2}{*}{$\begin{array}{l}\text { 利用ルート } \\
1 \text { 、東名 }\end{array}$} \\
\hline & \multirow{2}{*}{$\begin{array}{l}\text { 1、男 } \\
\text { 2、女 }\end{array}$} & \multirow{2}{*}{$\begin{array}{l}\text { 1、業務 } \\
\text { 2、観光 }\end{array}$} & 1〜11人 & \\
\hline & & & 時間带 (時) & 2、中央道 \\
\hline 1、 $1 \sim 10$ & 年踰 (藏) & 曜日 & $1,8 \sim 11$ & 1、名神 \\
\hline 2、 $11 \sim 40$ & \multirow{6}{*}{$\begin{array}{ll}1, & 18 \sim 30 \\
2 、 & 31 \sim 40 \\
3 、 & 41 \sim 50 \\
4 、 & 51 \sim\end{array}$} & 1、日曜 & 2、 $12 \sim 13$ & 2、東名阪 \\
\hline 3、 $41 \sim 100$ & & 2、平日 & 3、 $14 \sim 16$ & 1、中国道 \\
\hline 4、 $101 \sim 200$ & & （火曜、木曜） & 4、 $17 \sim 21$ & 2、山陽道 \\
\hline 5. $201 \sim 365$ & & 落時問選好性 & 繁経済性 & 安金性 \\
\hline 料金車種 & & \multicolumn{3}{|c|}{ 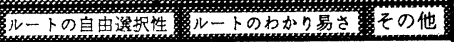 } \\
\hline $\begin{array}{l}\text { 1、普通車 } \\
\text { 2、大型車 }\end{array}$ & & \multicolumn{3}{|c|}{$\begin{array}{l}\text { 0、その評価要因を経路遶択の滕に考唐していない } \\
\text { 1、考慮している }\end{array}$} \\
\hline
\end{tabular}

まず、基本LISRELモデルで用いる観測変数と潜在 变数について本研究に抢ける定義を行う。図 -5 に示 すように、内生的潜在变数は、前節までで取上げた経 路選択評価要因のそれぞれに対応する「時間選好 性」「安全性小「ルートのわかり易さ」、「ートの自 由選択性」「経済性」と「ルート特性」の6つを設定 した。また、外生的潜在変数には、「個人属性」と「卜 リップ特性」の2つの変数を仮定する。また、表-3は、 これら観测変数のモデル上の数量的表現方法を示し たものである。

本モデルの因果棈造は、具体的には以下のように 考えている。ここで、「ルート特性」とは競合するど ちらのルートを選択するかを指す变数である。これ 法、「経路選択評価要因」がそれぞれかかわる潜在変 数により規定される。さらに、それら潜在変数は、 「個人属性」と「トリップ特性」により規定されると 


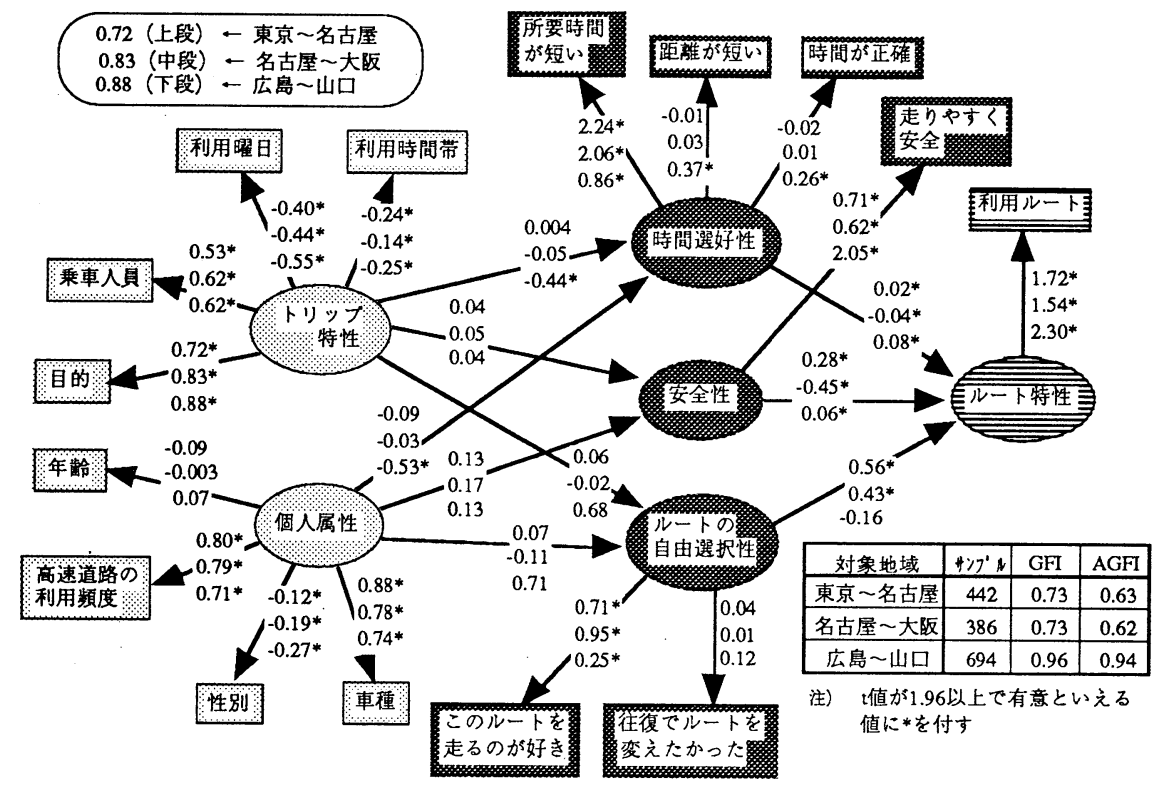

図-6 経路選択要因の構造モデル（基本モデル）

との割合差 $(9 \%)$ が最大 であることがわかる。一 方、基本モデルの推計結果 を眺めてみると、3つの評 価要因の中で「ルートの自 由選択性」の間接効果の絶 対值が 0.96 と最大であり、 パラメータが正であるこ とから、「利用ルート」へ の規定力が最も大きいの は「ルートの自由選択性」 であり、さらに、中央道利 用者ほどそれを考慮するこ とが示されている（パラ メータが負の場合は表 -4 における1のルート、正の 場合は2のルート利州者ほ 仮定している。また、モデル上の変数の組み合わせ およびパスダイヤグラムに関しては、ルート特性変 数を除く $5 つ$ つ生的潜在变数をできるだけ多く取 り入れる方法でパスダイヤグラム構成を含め試行錯 誤的にパラメータ推定を繰返すこととした。

その結果、図-6に示す因果構造のモデル形式にお いて 3 地域比較可能な最良のケースを得ることがで きた。なお、「ルートのわかり易さ」の潜在变数を取 り入れたモデルでは収束しないケースがあり結果的 には用いられていない。

表-4は、経路選択評価要因と「利用ルート」との 関係について、基礎集計結果と基本モデルによる推 計結果との整合性を示したものである。例えば、こ の表の東京〜名古屋間に着目すると、基礎集計では 「時間選好性」「安全性」「ルートの自由選択性」の 3 評価要因については、中央道の方がその構成割合 が高く、特に「ルートの自由選択性」において東名 どその評価要因を考慮することを意味する)。このよ うに、基礎集計結果と一致した結果が得られている 場合には、整合性の闌に○を付している。

また、残りの対象地域についてもその整合性を眺 めると、基本モデルによる推計結果はいずれも基礎 集計結果と整合し、当該地域特有の性質をうまく表 現できていることがわかる。

さらに、基礎集計結果の中で普通車は「時間選好 性小大型車は「安全性」を考慮することが明らかに なっているが、表 -5 より利用車種に関する間接効果 の推計結果はこの特性と整合している。

このように、ここで構築した基本モデルは「個人 属性・トリッブ特性」と観測変数間の因果関係および 「経路選択評価要因」と「利用ルート」間の因果関係 については、比較的良好な結果を得ることができた。 しかし、「個人属性・玔ブ特性」と「経路選択評価要 因」間のパラメータに着目してみると、多くのパス係

表-4 経路選択評価要因と利用ルートの因果関係にから見たモデルの整合性

\begin{tabular}{|c|c|c|c|c|c|c|}
\hline \multirow{2}{*}{ 対象地域 } & \multirow{2}{*}{ 評価要因 } & \multicolumn{2}{|c|}{ 基礎集計結果 } & \multicolumn{2}{|c|}{ 基本㔚 N推計結果 } & \multirow{2}{*}{ 整合性 } \\
\hline & & 構成割合の差 & 利用 $w-1$ & 閏接効果 & 利用 $N-1$ & \\
\hline \multirow{3}{*}{$\begin{array}{l}\text { 東京 } \\
\text { ～名古屋 }\end{array}$} & 時間選好性 & $1 \%$ & 中央道 & 0.03 & 中央道 & 0 \\
\hline & 安全性 & $3 \%$ & 中央道 & 0.48 & 中央道 & 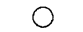 \\
\hline & N-トの自由選択性 & $8 \%$ & 中央道 & 096 & 中央道 & 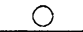 \\
\hline \multirow{3}{*}{$\begin{array}{l}\text { 名古屋 } \\
\text { ～大阪 }\end{array}$} & 時間選好性 & $7 \%$ & 名神 & -0.06 & 名神 & $U$ \\
\hline & 安全性 & $9 \%$ & 名神 & 066 & 名神 & 0 \\
\hline & N-トの自由選択性 & $2 \%$ & 東名阪 & 0.66 & 東名阪 & 0 \\
\hline \multirow{3}{*}{$\begin{array}{c}\text { 広島 } \\
\stackrel{\sim}{\sim} \text { 山口 }\end{array}$} & 時間選好性 & $11 \%$ & 山陽道 & 0.18 & 山陽道 & 0 \\
\hline & 安全性 & $14 \%$ & 山陽道 & 0.14 & 山陽道 & 0 \\
\hline & Nートの自由選択性 & $7 \%$ & 中国道 & 082 & 中国道 & 0 \\
\hline
\end{tabular}

表-5 利用車種との因果関係から見たモデルの整合性

注）・各地域において棈成割合の差および間接奻果が最大の評価要因に網を掛けた。

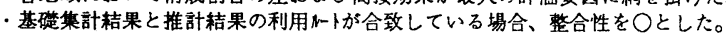

\begin{tabular}{|c|c|c|c|c|}
\hline \multirow{2}{*}{ 対象地域 } & \multirow{2}{*}{ 評価要因 } & \multicolumn{2}{|c|}{ 基本括 N推計䊅果 } & \multirow{2}{*}{ 整合性 } \\
\hline & & 間接効果 & 車種 & \\
\hline 東袁 & 時間選好性 & -0.08 & 普通車 & $\mathrm{O}$ \\
\hline ～名古屋 & 安全性 & 0.11 & 大型車 & 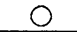 \\
\hline 名古屋 & 時間選好性 & -0.02 & 普通車 & 0 \\
\hline ～大阪 & 安全性 & 0.13 & 大型車 & 0 \\
\hline 広島 & 時間選好性 & -0.39 & 普通車 & 0 \\
\hline ～山口 & 安全性 & 0.10 & 大型車 & 0 \\
\hline
\end{tabular}

注）表中の整合性の判断は、基碳集計分析における 車種別評価要因構成(\%)のシェアの違いにもとづ き行った。 
数值は有意な值になっていない。これは経路選択評 価要因を規定する変数が他に存在する可能性を示唆 しており、以下では「車線数」や「制限速度」等の道 路側の条件に着目することにし、モデルの改良を加 えることにする。

\section{（2）道路側の条件を考慮したモデルへの改良}

ここでは、定性的評価要因を規定すると考えられ る道路側の条件に着目し、基本モデルで取り上げら れなかった因果関係を表現するものである。また、こ の改良モデルは、個人サンプル単位の非集計型の基 本モデルに対比させて、対象地域関連のODペア単位 のモデル構造へ改良することを最終的に意図するも のである。そのために基本モデルでの「個人属性・卜 リップ特性」を用いる代わりに図 -7に示すような新 たな観測变数を導入している。(なお、ここで新たに 導入した観測变数のうちで時間差・料金差は、便宜的 に利用ルートと非利用ルートとの差で定義してい る。)

改良モデルにおける経路選択評価要因は、外生的 潜在変数との関係から、「時間選好性」「安全性」「経 済性」の3つを取り上げることにする。また、新たに 構築するモデルのためにデータの再加工を行ったが、 東京〜名古屋間に扔いては必要最低限のサンプルが 抽出できなかったため、以下では、名古屋〜大阪、広 島〜山口の 2 地域間について議諭する。

図-8は、改良モデルに抢けるパスダイヤグラムと それにより推計された両地域のパラ メータを示したものである。「経路選択 評価要因」が「利用ルート」を規定して いるのは基本モデルと同じである。ま た、「時間選好性」は「時間サービス性」 と「快適性」によって規定され、同じく 「安全性」は「快適性」によって、「経済 性」は「料金サービス性」によって規定 され、さらにこれら外生的潜在变数は 政策変数としてのいくつかの観測変数 との因果関係を仮定している。

実際に推計された結果の中で、まず3 つの「経路選択評価要因」と「ルート特 性」との因果関係に着目してみると、パ ラメータの符号条件、 $\mathrm{t}$ 值の両者ともに 良好な結果を得ている。具体的には、

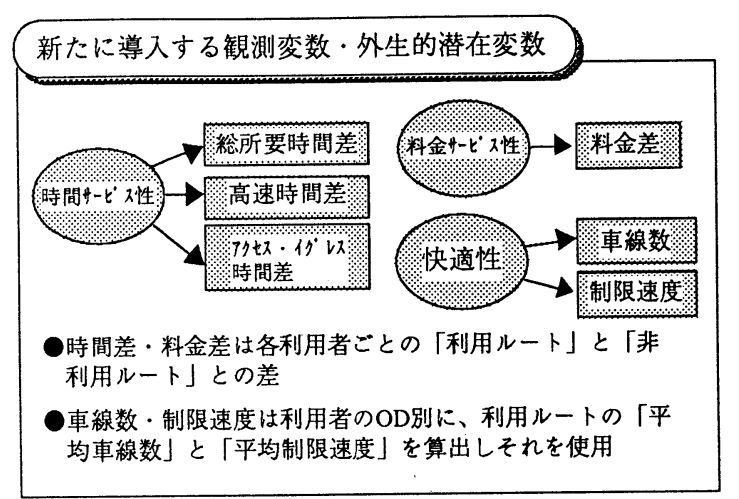

図-7 新たに導入する観測変数・潜在変数

1）名古屋〜大阪において、ルート特性への規定力 は「経済性 (0.43)」「安全性 (-0.15)」「時間選好性 (0.09)」の順で強く、さらに符号条件から東名阪利用 者ほど「経済性」を、名神高速利用者ほど「安全性」 「時間選好性」を考慮することを示している。これは 基礎集計結果に整合している。

2）広島～山口においては、「安全性 (0.12)」「時間 選好性 (0.09)」「経済性 (-0.003)」の順でルート特性 への規定力が強く、さらに符号条件から山陽道利用 者ほど「安全性」「時間選好性」を、中国道利用者ほ ど「経済性」を考慮しているといえ、これも基礎集計 結果と整合している。

3）地域間比較の観点からは、名古屋〜大阪におい て「ルート特性」への規定力が「経済性」で最大 （0.43）になっていることに対して、2ルート間に料金 差がない広島〜山口ではその規定力が最小（-0.003）
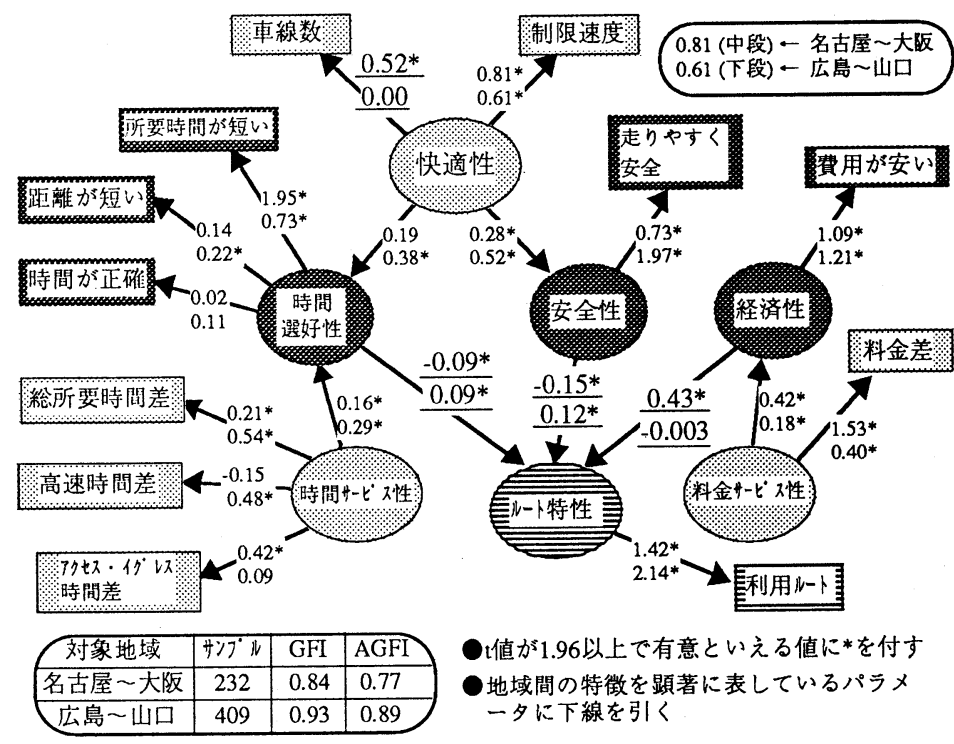

図-8 経路選択評価要因の因果構造モデル（道路側条件を導入したタイプ） 
になっており、本モデルが地域の特徵をよく表現で きているといえる。

4）また、新たに導入した変数の中で「時間サービス 性」に着目すると、「時間選好性」への規定力は名古 屋〜大阪では「アクセス・イグレス時間差」広島〜 山口では「粉所要時間差」が最も強いことがわかる。 一方、「快適性」に関しては、どちらの地域において も制限速度が速いほど利用者は「安全性」「時間選好 性」を考慮しやすいことが示されている。(ここで、 広島〜山口で「快適性」と「車線数」間のパラメー タが0になったのは、この地域においては雨経路の 車線数に違いがないことによる。）

5）そして、前節のモデルでは有意とならなかった 外生的潜在変数と経路選択評価要因との因果関係も 良好な值になった。また、モデルの適合度を表す GFI、AGFI を眺めてみると、名古屋〜大阪では基本 モデルの時に比べその值が向上している。これは、 この地域において経路選択に大きく影響している 「経済性」という評価要因をモデルの中に導入したこ とを反映した結果であろう。

以上のように、この改良モデルは今後道路侧の 種々の条件が変化したとき、それに伴う因果構造へ の影響が計量的に把握できるという利点も持ってい る。

\section{4 おわりに}

本研究は、高速道路経路選択行動における評体要 因構造特性を把握するため、LISRELモデルの適用を 試みるとともに、その有効性検証を地域間比較分析 を通じて行ったものである。

この中で、まず高速道路利用者意識評価デー夕に 基づき経路選択行動を規定する定性的要因の抽出と 分析対象ルート特性の実態把握が行われた。次いで これを踏まえて定式化された基本 LISREL モデルで は、「時間選好性」「安全性」「ルートの自由選択性」 といった評価要因と利用ルートとの因果関係の表現 が対象ルートに関する基礎集計結果（ルート特性） に整合する形でできることが示された。次に、道路 側の条件を考慮した改良 LISREL モデルでは、新た に「時間サービ性」や「経済性」といった潜在変数や 「車線数」「制限速度」などの観測変数を導入するこ とにより、基本モデルに比べ全体的な適合度の高い
因果䊈造の表現が可能となった。これらの検討結果 から、共分散棈造分析手法（LISREL モデル）は、経 路選択に扔ける評価要因構造の表現にとって有効な 方法論であることが確かめられたといえる。

ただし、更なるモデルの洗練化ならびに将来予測 への適用性を目指す上では、いくつかの重要な課題 が残されている。例えば、経路選択行動における規定 要因は多岐にわたり、かつルートの特性にも依存す るために沉用的なモデル構造（パスダイアグラム構 成）を目的としてモデルの同定化を試みたが、3地域 問比較が可能なケースは必ずしも全ての定性的要因 を考虑できておらず、最良のモデルの提案とはなっ ていない。また後半の改良モデルでは、最終的には交 通需要予測へのモデル展開を意識してODペア単位で 集計的な扱いを一部試みたが、今回は分析対象デー 夕数の不足により十分な検討がなされていないため、 その点での有効性検証は今後の課題となっている。

\section{《謝辞〉}

本研究の遂行にあたり、高速道路利用者アンケート調査 データに関しては、日本道路公団・高速道路調査会の協力の もとで分析データとしての入手が可能となった。ここに関係 各位に謝意を表します。またLISRELモデル構築の一部分に関 して都市交通計画研究所からの研究助成を受けたことを記し、 ここに謝意を表します。

\section{<参考文献>}

1) 高速道路調査会: 平成 6 年度高速道路の交通量推計手法の 改善に関する調査報告書, 日本道路公団,pp.6〜69,1995.

2）森川高行,佐々木邦明：主観的要因を考慮した非集計離散 型選択モデル, 土木学会論文集,No.470,pp.115 124,1993.

3) 山本俊行, 藤井聡, 北村隆一: 交通機関選択要因の主観的重 要度の構造に関して, 土木計画学研究 - 講演集, No.17,pp.435 436,1995.

4) 大東延幸,原田昇,太田勝敏：動く歩道の利用者の意識につい ての研究, 土木計画学研究·講演集,No.19 (2),pp.465 468,1996.

5）西井和夫,古屋秀樹, 佐藤俊通,高橋和已：地域社会から見 た高速道路整備に関する定性的評価の構造分析：共分散構 造分析による, 土木計画学研究 ·論文集,No.13,pp.93〜 $101,1996$.

6）西井和夫, 原田昇, 近藤大介,田名部淳：高速道路経路選択 行動における評価要因間の因果構造モデルの地域間比較, 土木計两学研究 ·講演集, No.20 (2) ,pp.633 636,1997. 
高速道路経路選択行動に扔ける評価要因の因果構造特性：地域間比較分析

西井和夫、原田昇、近藤大介、田名部淳

本研究では共分散構造分析の適用によって個人属性・経路選択評価要因・利用ルートを変数とした基本 モデルの構築と、道路側の条件を変数として考慮した改良モデルを構築し、これら評価要因の因果関係を

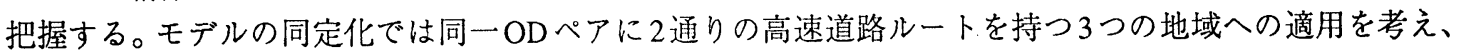
そのパラメータ推計結果と基礎集計結果との対比抢よび地域間比較を通じて、LISRELモデルがどのよう に経路選択行動の評価要因構造を表現できるのか、その有効性を検証する。その結果、推計されたモデル

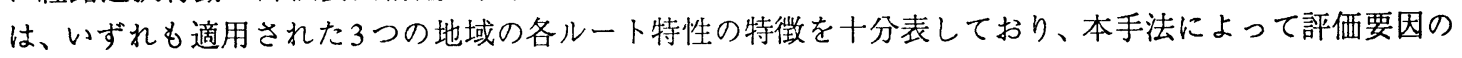
因果構造の把握が可能であったことがわかった。

Some Characteristics of Causal Structures underlying Highway Route Choice Behavior : A Comparative Analysis

by Kazuo NISHII, Noboru HARATA, Daisuke KONDO and Jun TANABE

The purpose of this paper is to develop a model for identifying the causal structures underlying route choice behavior by using a LISREL technique. In this paper, one prototype model is calibrated in order to compare with the results from its application to three areas. The qualitative factors determining route choice behaviors are incorporated into the model. The five latent variables such as time and cost saving convenience, comfort, safety, and caprice are used in the model Also, the improved model is developed considering level of service in the route as an exogeneous variable. These results indicate that both types of LISREL model have capability of representing causal structures between those factors. 